\title{
Social Policy in Social Work PhD Programs in the United States
}

\author{
Elizabeth Lightfoot ${ }^{\mathrm{a}}$, John Gal ${ }^{\mathrm{b}}, \&$ Idit Weiss-Gal ${ }^{\mathrm{c}}$
}

${ }^{a}$ School of Social Work, University of Minnesota, 1404 Gortner Ave, St. Paul, MN 55108, USA

${ }^{b}$ School of Social Work and Social Welfare, Hebrew University of Jerusalem, Jerusalem, Israel ${ }^{c}$ School of Social Work, Tel Aviv University, Tel Aviv, Israel

This is an Accepted Manuscript of an article published by Sage Publications in Research on Social Work Practice in June, 2017, available online:

https://doi.org/10.1177/1049731517710328

It is deposited under the terms of the Creative Commons Attribution-NonCommercialNoDerivatives License (http://creativecommons.org/licenses/by-nc-nd/4.0/), which permits noncommercial re-use, distribution, and reproduction in any medium, provided the original work is properly cited, and is not altered, transformed, or built upon in any way. 


\begin{abstract}
While there has been a long-standing concern about the role of policy within social work education and social work practice, most of the emphasis has been on social work education at the BSW and MSW levels. This article examines policy education at the PhD level. It first explores how policy is taught in social work PhD programs in the United States, with an emphasis on how policy theory and research methods are included. Next, it explores the nature of policy research conducted by social work PhD students in the United States by examining the policy content in their doctoral dissertations. This study finds that policy research methods and policy study theories are only taught in a minority of social work $\mathrm{PhD}$ programs. In addition, very few social work doctoral dissertations have a policy focus. Of those that do, over half focus on program evaluation.
\end{abstract}

\title{
Introduction
}

There has been a long-standing concern about the role of policy within the field of social work in the United States (Byers, 2014; Figueira-McDonough, 1993; Goldberg, 2012; Lens \& Gibelman, 2000; Pomeroy, 2010; Reisch, 2000). While social work has always included community-level work and engagement in the policy arena in the form of policy practice and policy-related research, as a core part of the profession (Coombs-Orme, 1988), there has been a growing unease that social work is ceding the field of social policy to other professions. There have been a number of initiatives aimed at promoting policy and macro-oriented concerns at the MSW level or in encouraging social work researchers to become more explicit how their 
research has policy implications, but there has been little work at the doctoral level to better train future educators and researchers in policy. This article is a first step in understanding how the field of policy is included in social work $\mathrm{PhD}$ programs in the United States, by examining how policy is taught in PhD social work programs, and the nature of policy research conducted by $\mathrm{PhD}$ students in doctoral dissertations.

Policy has historically been an important part of social work in the United States, and the National Association of Social Workers' (NASW, 2008) Code of Ethics specifically calls on social workers to be active in the policy arena. Social work has prided itself on being a valuesbased profession (Reisch, 2016), and a key component of this has been to call attention to social problems and to advocate for policy change that address these social problems with the intent to improve the lives of individuals and families (Jansson, 2013; Mizrahi \& Morrison, 2013; R. L. Schneider \& Netting, 1999; Stuart, 1999). Despite the strong emphasis on policy and advocacy as a key part of social work and growing efforts to develop an emphasis on policy in social work education on the BSW and MSW levels (Weiss-Gal, 2016), engagement in policy practice among social workers in the United States is relatively limited (Hoefer, 2013).

The NASW conducted the most comprehensive surveys of social workers' roles and tasks nearly a decade ago. According to the NASW's 2004 benchmark survey of licensed social workers (Whitaker, Weismiller, \& Clark, 2006), only $1 \%$ of respondents spent $20 \mathrm{hr}$ or more in a policy-related role and only $30 \%$ spent any time related to policy, which was the least amount of time spent on any social work role other than research. A follow-up 2007 study of NASW members, both licensed and unlicensed, also found that respondents averaged spending only $1 \%$ of their time on policy or legislative development (Whitaker \& Arrington, 2008). While many 
social workers are politically active personally such as through voting, encouraging others to vote, or following policy issues in the news (Ritter, 2007; Rome \& Hoechstetter, 2010), few are engaging in policy practice as part of their social work position (Weiss-Gal, 2017).

There have been no similar studies conducted of social workers at the doctoral level, though there have been concerns that social work researchers and educators are also not sufficiently active in the policy arena. A new study of social workers in the United States, which will encompass social workers at all levels, including those with doctoral degrees, is currently in the planning stages, but at this point, it appears that social workers are not engaging in policy work to the degree suggested by the value base of social work (Reisch, 2016).

Some have attributed the dearth of social workers' engagement in policy work to the lack of emphasis on policy or community-level issues within social work programs, particularly at the MSW level. Although there have been calls for decades that schools of social work should be emphasizing the study of social policy in social work education (Fisher, 1995; McNutt, 1995; Mendes, 2003; Pawar, 2004; Weiss, Gal, \& Katan, 2006), there is still not a strong emphasis on social policy within social work education. According to the 2014 Annual Survey of Social Work Programs conducted by the Council on Social Work Education (CSWE, 2015a), of the 192 graduate programs responding to the survey, only 26 offered an MSW program specialization in policy and only $0.4 \%$ of MSW students enrolled in the United States were in a policy concentration. Even when combining all community-level concentration or macroconcentration together $($ community $=26$ programs; administration $=29$ programs; leadership $=7$ programs, nonprofit/public management $=9$ programs; policy $=10$ programs; and 
research $=1$ program), only $7.23 \%$ of MSW students are choosing to study in a community-level concentration.

There have been numerous studies exploring why so few BSW and MSW social work students are interested in community practice in general and policy in particular. For example, studies have shown that students entering social work programs already have a strong preference to work in direct practice and a weak interest in working in policy (Mizrahi \& Dodd, 2013; Reutebuch, 2006; Weiss, 2006; Weiss, Gal, \& Cnaan, 2004), and that this preference doesn't change substantially during their social work education. Another possible explanation is that there are few faculty interested in conducting policy or community practice-oriented research. One explanation for this might be the way that policy is taught within the BSW and MSW curriculum, which influences the interests of future social work doctoral students. The policy curriculum at the BSW and MSW levels is not heavily informed by empirical research nor are the common policy textbooks used. Policy is presented more as a background for understanding social work practice and/or a method for making change rather than a field of knowledge itself. Thus, BSW and MSW students are often not exposed to potential policy research-related questions such as questions related to policy decision-making, the policy process, or policy implementation.

Lamenting the state of community practice social work, the Association for Community Organization and Social Administration (ACOSA) commissioned Jack Rothman to do a survey of ACOSA members on the state of community practice in social work education, referred to now as the "Rothman Report" (2013). While the Rothman Report focused on macropractice in general, policy is included both in the justification for completing the report and in the findings. 
In this report, Rothman found little faculty support for the macro-related curriculum, a strong emphasis on clinical curriculum that detracted from macroissues, federal funding of clinical research that incentivizes faculty to focus on clinical concerns, lack of overall support from deans and directors, few macro-oriented faculty, and little interest in macroissue or policy issue among students.

Following the release of the Rothman Report, ACOSA established the Special Commission to Advance Macro Practice in Social Work (Special Commission) in 2013. There has now been a concerted effort to "make macro matter," with the Special Commission working on a social marketing campaign to increase the awareness of community practice issues in the field. While the emphasis of the Special Commission is primarily at the BSW and MSW level, two of its anticipated outcomes are related somewhat to doctoral education. These desired outcomes are "focusing on knowledge development in macroresearch" and "supporting the conducting of research for the purposes of development knowledge for community practice." There were five work groups established, and one of the work group's tasks was to "influence the Group for the Advancement of Doctoral Education (GADE) to recruit and produce more macro-oriented PhDs" (ACOSA, 2014, p. 2). While the Special Commission has not yet reached out to GADE regarding increasing the number of PhD students trained in policy or community practice research, the issue likely goes further than just recruiting more $\mathrm{PhD}$ students with these broader interests.

\section{Policy Research and Theory in Social Work Education}

There are several other recent social work policy initiatives at the national level. For example, the New York Community Trust (2015) established the Fund for Social Policy 
Education and Practice to promote initiatives that increase the awareness of policy among social work students and practitioners. This fund supported CSWE in establishing the Coalition for Policy Education and Policy Practice in Social Work in 2015, which intends to raise the status of policy within social work education (CSWE, 2015b). CSWE, in partnership with NASW, also established a social work policy fellowship in 2016, intended to provide an opportunity for doctoral students or postdoctoral fellows to engage in policy research and learn more about policy practice (NASW, 2016). Likewise, the Society for Social Work and Research (2016) is also starting a new policy initiative, and held its first Annual Policy Forum in 2016, which intends to highlight faculty and others that advance policies that are supported by social work research. These initiatives are all important steps in encouraging social work students to include a focus on policy in their studies and to help encourage social work faculty to be cognizant of how social work research can inform policy.

While this renewed emphasis on policy by national organizations is a positive step, one important area of that has not been addressed is how future faculty and researchers learn about policy during their doctoral programs. Recruiting more students into $\mathrm{PhD}$ programs with policy interests will not necessarily make them good policy researchers or good policy educators. The quality of their $\mathrm{PhD}$ training is vital. Further, to recruit the brightest policy-oriented $\mathrm{PhD}$ students into social work $\mathrm{PhD}$ programs, social work $\mathrm{PhD}$ programs have a lot of competition. For those interested in doing doctoral studies in social policy or social welfare policy, there are currently a number of options aside from a PhD in social work. For example, in 2015, there were 87 doctoral programs in public policy or administration (Network of Schools of Public Policy, Affairs, and Administration [NASPPAA], 2015), and these are only $\mathrm{PhD}$ programs that exist within a program that is a member of the NASPPAA. There are many other $\mathrm{PhD}$ programs in policy 
studies, public policy, and policy analysis that are not part of NASPPA, and doctoral students can also study policy in other doctoral programs in fields such as economics, political science, or sociology.

While all applied social science $\mathrm{PhD}$ programs should cover content in quantitative and qualitative research, $\mathrm{PhD}$ programs that are more specifically focused on policy would ideally focus on the types of theoretical and methodological content based on the policy fields emphasized in their programs. According to Smith and Larimer (2017), in the third edition of their landmark review of the policy studies field, The Public Policy Theory Primer, there are seven fields of policy study, each with their own types of research questions asked, conceptual frameworks and methodological approaches. A brief review of these seven fields is useful for ascertaining the depth and breadth of policy training in social work doctoral education and for ascertaining which policy studies fields fit best with social work or particular social work doctoral programs.

The first of the seven fields of policy study described by Smith and Larimer (2017) is policy and politics. In this policy field, researchers are interested in political scienceoriented questions regarding types and classification of policies, such as distributive, redistributive, or regulatory policies, and the intersections of policy and politics. This field tends to be less theoretical and often relies on quantitative analysis and qualitative typologies.

Smith and Larimer (2017) call the second field policy makers and policy-making institutions, but this field is primarily interested in policy decision-making. This field focuses upon who makes policy decisions and why they make them; draws heavily from rational choice theory; and often relies on formal theory, modeling, and quantitative analysis. 
The third field is the policy process (Smith \& Larimer, 2017). This policy field concerns itself with the nature of the policy-making process including questions related to social problem identification and how policy change happens. Some of the key theoretical frameworks of the policy process include Kingdon's (1995) multiple streams model, the advocacy coalition framework (Sabatier \& Weible, 2007), and policy diffusion models (Berry \& Berry, 1990).

The fourth field is policy design. The field of policy design concerns itself with the content of policy, with an emphasis on the values represented in particular policies (Smith \& Larimer, 2017). Researchers in the policy design field are often engaged in critical analysis related to questions regarding the social construction of policy groups or the perceptions of policy problems and solutions. For example, one subfield of policy design is the narrative policy framework, which examines how policy narratives can affect public opinion and policy outcomes (Smith \& Larimer, 2017).

The fifth field that Smith and Larimer (2017) describe is the field of policy analysis. The policy analysis field is concerned with studying policy choices and is informed by both welfare and behavioral economics. Policy analysis has traditionally been seen as a rationalist approach, employing methods like cost-benefit analysis, though more postpositive methods are also employed, such as participatory policy analysis that is grounded in deliberate democracy traditions. Rothman (2013) argues that the policy analysis field is the field that scholars of policy from social work most engage.

The sixth and sevenths field are policy evaluation and policy implementation, which both examine the outcomes of policy. Policy evaluation examines the impact of particular policies and is a type of research that is often taught in the MSW curriculum. Policy implementation is 
concerned with what was actually done. This policy field is concerned with how or why policies succeed or fail, with an emphasis on how policy decisions were translated into action.

These policy studies fields are all interested in the nature of policy, which is substantively different from policy-related research that attempts to shows the policy implications of research. Social work researchers are much more likely to engage in policy-related research rather than research into the nature of policy. While policy implications of research are vitally important, they don't advance our knowledge into how and why policy change happens. The seven policy studies fields are all directly relevant to the field of social work and social welfare, and improving the state of social work knowledge in these policy fields can help provide important evidence for social workers involved in policy practice.

However, social work scholars are not likely to conduct research in any of these policy fields if they are not learning the theories and associated research methods of these fields. The following section examines how policy is currently taught in $\mathrm{PhD}$ programs in the United States.

\section{How Is Policy Taught in PhD Programs in the United States?}

A review of the curriculum was conducted of all $\mathrm{PhD}$ programs ranked in the top 50 graduate social work programs according to the U.S. News and World Reports (2016), noting that this ranking system is inherently flawed as it is based only on reputation and does not focus on doctoral education. In 2016, there were 52 social work programs in the United States ranked in the top 50 due to ties in rankings, and of these, 51 had a $\mathrm{PhD}$ program. For this analysis, we were able to obtain materials regarding the curriculum, course descriptions, and/or syllabi of 50 or the $51 \mathrm{PhD}$ programs. The curriculum was reviewed to ascertain both the presence of policy in 
the curriculum and how policy content, theory, and research were covered in the curriculum. This review is limited to the resources that were available in print. It is likely that the specific policy topics presented relies heavily on the knowledge of policy background, theoretical perspective, and research interests of the instructors teaching the courses. Further, we acknowledge that many $\mathrm{PhD}$ students can receive excellent training in policy theory and research through mentoring relationships both within their schools of social work and from policy scholars across universities.

The majority of the $\mathrm{PhD}$ programs reviewed $(75 \%, n=37)$ did have some policy component within their curriculum. Of the 13 programs that did not have any required policy component, 2 had very few required courses at all. PhD students in these $13 \mathrm{PhD}$ programs, and nearly all of the other $\mathrm{PhD}$ programs reviewed, had the opportunity to take electives in other departments to gain knowledge and skills related to policy content, policy theory, and policy research. It is likely that students with a strong interest in conducting policy research could find courses on policy theory and policy research within their universities or even take courses at other universities. But, as the field of social work maintains that policy is a core component of its field, this review focused on the policy content, theory, and research courses within the schools of social work themselves.

When delving deeper into the type of policy components offered by the $37 \mathrm{PhD}$ programs that included some coverage of policy, it is quickly apparent that there are great discrepancies in how policy is presented to $\mathrm{PhD}$ students. The variations of how $\mathrm{PhD}$ programs included policy are as follows: (1) policy included as a topic within a general theory course; (2) policy as a standalone course focusing on policy content and/or policy theory; (3) policy analysis conceptualized 
as the application of frameworks, models, or schemas; and (4) in-depth coverage of policy research.

\section{Policy Included as Part of General Theory Course}

Of the $37 \mathrm{PhD}$ programs that had policy content, 3 included policy content solely as part of a general theory class, such as in a practice theory course or a theories of change course which covers theories of change ranging from change at the individual level to organizational level, which includes policy changes. Inclusion of policy theory into theory classes is important but usually would not be at a sufficient depth in such a course to provide a foundation for conducting policy-related research.

\section{$\underline{\text { Policy Content/Theory Courses }}$}

About one third of the $\mathrm{PhD}$ programs reviewed $(68 \%, n=34)$ offered stand-alone policy classes. Of these stand-alone courses, 14 of the PhD programs had stand-alone courses focused primarily on presenting substantive policy knowledge, such as policy history, policy processes, policy components, and political institutions, and policy theory. These courses typically provided coverage of policy issues at a much deeper level than would be at an MSW class and presented readings that discussed results of policy research. These courses often included in-depth coverage of some types of policy theory, particularly theories of the welfare state and theories of implementation. In some $\mathrm{PhD}$ programs, these stand-alone courses were almost entirely about theories of the welfare state, which are an excellent grounding for all PhD students in social work. These content/theory courses are extremely useful for $\mathrm{PhD}$ students for helping to understand the policy implications of their research and are likely useful for those who might be 
teaching introductory policy courses in the future. What these content/theory courses lack though is an in-depth introduction of policy research or theory outside of the field of policy implementation, which would be useful for those interested in conducting policy research or adding to the knowledge bases of other policy fields that would have direct relevance for improving policy practice.

\section{Policy Analysis as Frameworks, Models, or Schemas Courses}

In nine of the programs, policy analysis, conceptualized as applying frameworks, models, or schemas, was covered. These courses conceptualized policy analysis as applying a framework to a particular policy proposal or existing policy, such as Chambers and Bonk's (2012) criteria from their Social Policy and Social Programs: A Method for the Practical Public Policy Analyst or Bardach and Patashnik's (2015) eightfold path for policy analysis from his Practical Guide for Policy Analysis: The Eightfold Path to More Effective Problem Solving. The application of policy analysis frameworks is vital for understanding policy. However, these courses tend not to go further than applying frameworks and did not present an in-depth coverage of the theory and methodologies of the policy field of policy analysis. These courses typically did not include an in-depth exploration of policy analysis tools used by policy analysts or cover policy research methods typically used by policy researchers. Many of the schools that offered a course that covered policy analysis as a framework, model, or schema also introduced policy content into other courses, such as theory courses, and also offered in-depth coverage of substantive knowledge. PhD students studying in these programs should have a very solid base from which to understand the policy implications of their own research and to teach MSW level policy courses. 


\section{$\underline{\text { In-Depth Policy Research }}$}

Of the $50 \mathrm{PhD}$ programs reviewed, only $11(22 \%) \mathrm{PhD}$ programs had courses that included a substantial amount of content on policy research methods. The policy research methods included in these $\mathrm{PhD}$ programs varied. Some programs included content or entire courses on policy analysis tools such as cost-benefit analysis, cost-effectiveness analysis, and forecasting or microsimulation analysis. Others focused primarily on policy research, introducing students to common policy research methods such as the comparative case study method, implementation research, secondary data analysis, or archival research. Others included a focus on both. Three of the programs that offered more in-depth policy research courses had policyrelated tracks or dual degree programs within their $\mathrm{PhD}$ program, but the other eight $\mathrm{PhD}$ programs required a policy research course of all students. All of the PhD programs that included policy research also included modules on policy content or policy theory. $\mathrm{PhD}$ programs that offered courses in policy research were also likely to present more varied policy-related theories either within the policy research course or in other policy or theory courses, often drawing from fields that play key roles in policy analysis, such as economics, sociology, political science, and public administration. These courses often presented more of the commonly used theories in various policy subfields' field (Smith \& Larimer, 2017), including theories of the policy process, such as Kingdon's multiple streams theory; theories of policy decision-making, such as Ostrom's (2011) Institutional Analysis and Development framework; or theories of policy design, such as that of Schneider and Ingram $(1995,1997)$. However, not all $\mathrm{PhD}$ programs that offered policy research courses accompanied the policy research methods content with the inclusion of these types of core policy theories. 


\section{Policy as a Subject of Doctoral Dissertations in the United States}

One way of assessing the degree of interest in policy among $\mathrm{PhD}$ candidates in social work and to determine the impact of the social work policy curriculum is to examine the dissertations that are written by the participants in doctoral programs at schools of social work. A number of quantitative studies focusing upon doctoral dissertations have been undertaken in the United States and other countries (Horton \& Hawkins, 2010; Lyons, 2002; Scourfield \& Maxwell, 2010) in order to provide a potentially useful perspective of various aspects of doctoral studies. Social policy, as a subject of doctoral research, has not been the prime subject of these studies and, in most case, it is incorporated in wider macro-level categories in the analyses.

The findings in most of the existing studies indicate that policy has enjoyed very limited interest in the research of doctoral candidates in social work. In their study of dissertations in the United States published over a 10-year period between 1998 and 2008, Maynard, Vaughn, and Sarteschi (2014) found that macropractice (broadly defined as policy, administration, and community) comprised $18 \%$ of the social work practice domains addressed and concluded that there were "three times more dissertations focusing on micro practice than macro practice" (p. 283). Similarly, Fogel and Ersing (2016) studied macrocontent in doctoral dissertations listed in the ProQuest database from 2000 to 2009 . They found only about $8 \%$ of dissertations focused on macropractice overall (broadly defined as policy, administration, community, or other), and only about $2 \%$ focused specifically on policy. In a recent study on doctoral dissertations in social work in Taiwan (Shek, Hua Lee \& Yan Tam, 2007), the authors found that $16 \%$ of the dissertations focused on organization and social law, which included studies on organizational management and social policy. 
In Canada, a study covering a 10-year period between 2001 and 2011 revealed that only 10 dissertations dealt with the subject of poverty/social policy during that period (Rothwell, Lach, Blumenthal, \& Akesson, 2015). In a Swedish study, the authors found that one third of social work theses undertaken in Sweden in the 1999-2009 period dealt with different forms of social phenomena, social problems, or social policy (Dellgran \& Höjer, 2012).

In order to offer a more focused examination of the study of policy in doctoral dissertations in social work studies in the United States, we undertook a review of doctoral dissertations devoted specifically to social policy issues during the 1995-2014 period. The goal of the analysis was to identify some dominant trends in doctoral dissertation research on policy in social work during the last two decades. As such, in the review, we examined only those dissertations, which had an explicit policy focus. The review adopted a methodology similar to that employed in other analyses of doctoral dissertations. It drew upon data from the Social Service Abstract database between 1995 and 2014. For the purposes of this analysis, accessible abstracts of dissertations that included "policy" in the title and that were undertaken in an institution in the United States were identified. In the initial stage, 130 dissertations were found. Dissertations not undertaken in doctoral programs in schools of social work were excluded from the review. The remaining abstracts and dissertations (in some cases) were then read by two of the authors. Dissertations that did not engage in some form of policy research but just discussed the implications for policy were removed from the final list. Fifty-six relevant dissertations were identified.

This methodology has obvious limitations and may have missed some relevant dissertations. It did not include unpublished dissertations or those not cited in the database. 
Similarly, we did not include dissertations with regard to which access to an abstract or to the full text was not possible. In addition to the dissertations examined, studies which may have focused upon social policy, but the term policy did not appear in the title, were not reviewed.

The quantitative analysis of the place of policy in doctoral dissertations in the United States during this period reveals some interesting trends. First, the policy dissertations were undertaken in a wide range of institutions, though several schools of social work produced a greater number of dissertations, generally up to five over the entire period. Second, diverse research methods were employed in the dissertations, though a quantitative approach was predominant. Half of the authors of the dissertations undertook a quantitative analysis of their data. Thirty percent were qualitative studies, while the remainder employed either a historical approach (12\%) or used mixed methods (8\%). These proportions appear to broadly reflect the dominant methodological trends in social work dissertations, as they emerged in the Maynard et al. (2014) study.

Third, while all of the dissertations were undertaken in U.S. schools, almost a quarter (23\%) focused upon social policies in other nations or engaged in comparisons between policies in the United States and other countries. These included a study on disability policies in Saudi Arabia (Alhammadi, 2000), an examination of social policy content in social work training in Central Europe (Williams, 2003), a comparison of AIDS policy in Mexico and the United States (Ferrales, 2004), and a study on the implementation of the United Nations Convention of on the Elimination of All Forms of Discrimination against Women in South Africa, India, and Turkey (Vohra-Gupta, 2010). 
The social work policy dissertations can be divided into six different foci of policy studies. The impact or implications of policy upon individuals $(n=23)$ was the most common of these and included dissertations that examined the impact of specific policies, such as the "don't ask, don't tell" policy toward the lesbian, gay, bisexual or transgendered members of the armed forces (Vaughn, 2015), or that of state language policies upon access to health services among the immigrant population (Kao, 2011). The dissertations in this category all fit into the policy evaluation field of policy studies. An example of this is a study on a natural experiment concerning child support for incarcerated noncustodial parents (Noyes, 2014). Another is an evaluation of the impact of individual development accounts on savings for homes among program participants (Grinstein-Weiss, 2005).

Diverse aspects of policy implementation were another focus of policy dissertations $(n=$ 9). These tended to specifically examine the ways in which policies were implemented. Thus, Thoren (2008) looked at the ways in which social workers implemented social assistance at the local level in Sweden, and Rountree (2005) studied the factors facilitating or impeding the availability of assessment of client's risk for HIV/AIDS and HIV/AIDS educational/prevention programming in domestic violence shelters in Arizona.

A second focus was dissertations that examined the policy process related to the development of specific policies $(n=11)$ and fit squarely into the policy process field of policy studies. Studies of this type included a study of the role of two philanthropic foundations in the development of U.S. policy in the fields of housing and homelessness (Carlin, 2012) and a dissertation that identified the factors that influenced the decision of state units on aging to adopt or not adopt cost sharing under the Older Americans Act (Moone, 2008). It also included studies 
employing a more historical perspective, such as a study of federal legislative hearings devoted to social security reform between 1993 and 2003 (Svihula, 2005). Only a few of these studies were framed as contributing to the broader knowledge base of the policy process.

Another foci included the political participation by policy stakeholders $(n=5)$, such as human service nonprofits (Mosley, 2006) and social work leaders in the health policy domain (Domanski, 1996). These studies fit within the policy makers and policy-making institution policy field. Another group examined the features of specific policies (four) and the factors associated with these, such as childcare subsidy policies and quality regulations in states in the United States (Kim, 2015), which also fit either within the policy evaluation field or policy design field. Finally, four dissertations focused on aspects of policy training in social work, which included the impact of a social welfare course upon the political interest and efficacy of students (Bernklau Halvor, 2013). This last category, while certainly relevant to policy, is more appropriately classified as education research rather than policy research.

\section{Discussion}

Based on this initial inquiry into social work $\mathrm{PhD}$ policy curriculum and policy content of social work dissertations, it is clear that there is much room for advancement in the area of policy research and theory at the doctoral level. While there is much variation in policy curriculum in $\mathrm{PhD}$ programs in the United States, only 11 of the 51 programs reviewed included curriculum of sufficient depth to provide a basis for conducting a policy dissertation. Much of the curriculum offered in social work $\mathrm{PhD}$ programs didn't align with any of the typical policy subfields but rather provided a solid basis for social work researchers to discuss the policy implications of this work. What was missing from the majority of the curriculum was an emphasis on policy theories 
within the various policy fields and policy research methods associated with the various policy fields.

As the theoretical basis of policy research and policy research skills are only presented in a minority of $\mathrm{PhD}$ programs, it is not surprising that there are so few social work policy dissertations. This study only found 130 dissertations over a 20 -year time period that related to social work policy and of these, only 52 were actually conducting policy research, with the others discussing policy implications of research or examining social work education related to policy. This is less than the 134 found by Fogel and Ersing (2016), but both are surprisingly low considering policy is a key part of the field of social work.

The policy content of the social work policy dissertations was concentrated in a few policy studies fields. Just about half of the dissertations focused on policy evaluation of specific policies. This fits well with how social work has presented policy through all levels of the social work curriculum, and policy evaluation is often taught as a stand-alone course at the MSW level as well. A particularly social work-related aspect of many policy evaluation dissertations was their emphasis on how policies impacted the individuals. This is the type of social work lens that is valuable for the field of policy. While policy evaluation is enormously important for social workers in the field, the policy evaluation field of policy studies as an academic discipline is the one that is the least likely to lead to knowledge generation (Smith \& Larimer, 2017).

Just over one fifth of the dissertations fit into the policy process subfield. The policy process subfield is closely linked to policy practice, and dissertations in this area can help develop evidence that could help further develop this field of practice. While policy practice education is a key part of social work education in the BSW and MSW levels, much of the 
research on effective lobbying, advocacy, and mobilizing currently is done by those in other fields. More social work scholars engaged in policy practice research will likely elevate the field of policy practice at all levels of education as scholars can help develop more evidence-based curriculum models, which in turn will help influence the field.

Similarly, just about one fifth of the dissertations fit into the policy implementation subfield. The policy implementation field fits well within administrative practice of social work, as social work managers and administrators are often tasked with implementing policies. In the same way that social work researchers studying policy process-related research can elevate the field of policy practice, social work researchers studying policy implementation can help bring new evidence to administrative practice.

The findings of these initial inquiries suggest that if the field of social work is interested in emphasizing the policy subfield of social work, social work doctoral education is an area that should not be ignored. Increasing the rigor surrounding policy research in social work $\mathrm{PhD}$ programs will likely help draw more policy-oriented scholars into the social work field and likely increase the percentage of doctoral students completing policy-related dissertations. And, while program evaluation designs are certainly appropriate for social work doctoral education, the more opportunities for broad policy research training that $\mathrm{PhD}$ students receive, the more likely they are to engage in research and contribute to other policy studies fields such as policy design, policy analysis, and the policy process. The more social work scholars are actively engaged in policy research, the more likely that social work programs will value policy and that evidencebased policy curriculum will be developed. This hopefully will have the added benefit that more social work scholars will be prominent in policy debates around social welfare policy issues. 
While activity is important at all levels for promoting the fields of policy practice and policy research within social work, a concerted effort at the doctoral level is vitally important as well.

\section{Declaration of Conflicting Interests}

The authors declared no potential conflicts of interest with respect to the research, authorship, and/or publication of this article.

\section{Funding}

The authors received no financial support for the research, authorship, and/or publication of this article.

\section{References}

Alhammadi, H. A. (2000). Future challenges: A study of the needs of adults with disabilities and related policies in Saudi Arabia (PhD dissertation). University of Denver, Denver, CO.

Association for Community Organization and Social Administration. (2014). Special commission launched to Bolster Macro practice in social work. Author. Retrieved from https://www.acosa.org/joomla/pdf/SpecialCommissioninfosheet-latest3-1814.pdf

Bardach, E., Patashnik, E. M. (2015). A practical guide for policy analysis: The eightfold path to more effective problem solving. Washington, DC: CQ press.

Bernklau Halvor, C. D. (2013). Increasing social work students' political interest and efficacy: The experience and impact of a social welfare policy course from the 
students' perspective ( $\mathrm{PhD}$ dissertation). Portland State University, Portland, OR.

Berry, F., Berry, W. (1990). State lottery adoptions as policy innovations: An event history analysis. Policy Studies Journal, 43, 309-332.

Byers, K. V. (2014). Reemergence of policy practice: A journey back to our roots. Advances in Social Work, 15, 34-50.

Carlin, A. E. (2012). Pollinators of social change: The role of philanthropic grant making in state level housing and homeless policy development ( $\mathrm{PhD}$ dissertation). Brandeis University, Waltham, MA.

Chambers, D. E. \& Bonk, J. F. (2012). Social policy and social programs: A method for the practical public policy analyst (6th ed.). Boston, MA: Pearson.

Coombs-Orme, T. (1988). Infant mortality and social work: Legacy of success. Social Service Review, 62, 83-102.

Council on Social Work Education . (2015a). 2014 Annual statistics on social work education in the United States. Alexandria, VA: Author.

Council on Social Work Education . (2015b). The coalition for policy education and practice in social work-Advancing equity and social justice. Alexandria, VA: Author.

Dellgran, P., Höjer, S. (2012). The politics of social work research-Ph.D. theses in Sweden. European Journal of Social Work, 15, 581-597.

Domanski, M. D. (1996). Correlates of political participation among social work leaders in the health policy domain (PhD dissertation). Columbia University, New York, NY. 
Ferrales, T. D. (2004). Deconstructing AIDS policy: A comparative analysis between Mexico and the United States (PhD dissertation). University of Texas at Austin, Austin.

Figueira-McDonough, J. (1993) Policy-practice: The neglected side of social work intervention. Social Work, 38, 179-188.

Fisher, R. (1995). Political social work. Journal of Social Work Education, 31, 194-203.

Fogel, S., Ersing, R. (2016). Macro-focused social work dissertations: A preliminary look at the numbers. Journal of Social Work Education, 52, 170-177.

Goldberg, G. S. (2012). Economic inequality and economic crisis: A challenge for social workers. Social Work, 57, 211-224.

Graduate School Rankings by U.S. News \& World Report: Social Work. (2016). U.S. News \& World Report Graduate School Rankings, 2016. Retrieved May 25, 2016, from http://grad-schools.usnews.rankingsandreviews.com/best-graduate-schools/tophealth-schools/social-work-rankings

Grinstein-Weiss, M. (2005). IDAs for housing policy: Analysis of saving outcomes and racial differences (PhD dissertation). Washington University, St. Louis, MO.

Hoefer, R. (2013). Social workers affecting social policy in the US. In Gal, J., Weiss-Gal, I. (Eds). Social workers affecting social policy: An international perspective on policy practice (pp. 161-182). Bristol, UK: The Policy Press.

Horton, E. G., Hawkins, M. (2010). A content analysis of intervention research in social work doctoral dissertations. Journal of Evidence-Based Social Work, 7, 377-386. 
Jansson, B. S. (2013). Brooks/Cole empowerment series: Becoming an effective policy advocate. Boston, MA: Cengage Learning.

Kao, D. (2011). State variations in linguistic competency policies and the effects on immigrant access to health services (PhD dissertation). University of Southern California, Los Angeles, CA.

Kim, W. J. (2015). Policy variations among states and impact on the choice of child care service (PhD dissertation). Michigan State University, East Lansing.

Kingdon, J. (1995). Agendas, alternatives and public policies. Boston, MA: Little, Brown.

Lens, V., Gibelman, M. (2000). Advocacy be not forsaken! Retrospective lessons from welfare reform. Families in Society: The Journal of Contemporary Social Services, $81,611-620$.

Lyons, K. (2002). Researching social work: Doctoral work in the UK. Social Work Education, 21, 337-346.

Maynard, B. R., Vaughn, M. G., Sarteschi, C. M. (2014). The empirical status of social work dissertations research: Characteristics, trends and implications for the field. British Journal of Social Work, 44, 267-289.

McNutt, J. G. (1995). The macro practice curriculum in graduate social work education: Results of a national study. Administration in Social Work, 19, 59-74.

Mendes, P. (2003). Teaching social policy to social work students. Australian Social Work, $56,220-233$.

Mizrahi, T., Dodd, S. J. (2013). MSW students' perspectives on social work goals and social activism before and after completing graduate education. Journal of Social Work 
Education, 49, 550-600.

Mizrahi, T.,, Morrison, J. (2013). Community organization and social administration: Advances, trends, and emerging principles. New York, NY: Routledge.

Moone, R. P. (2008). National policy diffusion of cost sharing in the 2000 reauthorization of the Older Americans Act (PhD dissertation). University of Minnesota, Minneapolis.

Mosley, J. E. (2006). The policy advocacy of human service nonprofits: How institutional processes and environmental conditions shape advocacy involvement $(\mathrm{PhD}$ dissertation). University of California, Los Angeles.

National Association of Social Workers. (2008). NASW code of ethics. Washington, DC: Author.

National Association of Social Workers . (2016). Social work HEALS doctoral \& policy fellowships. Washington, DC: Author.

Network of Schools of Public Policy, Affairs, and Administration . (2015). Doctoral programs. Retrieved from http://www.naspaa.org/students/graduate/schsearch.asp

New York Community Trust. $(2015,2)$. Grants will improve social work education. Grants Newsletter.

Noyes, J. L. (2014). Evaluating child support policy options for incarcerated noncustodial parents (PhD dissertation). The University of Wisconsin, Madison.

Ostrom, E. (2011). Background on the institutional analysis and development framework. Policy Studies Journal, 39, 7-27. 
Pawar, M. (2004). Social policy curricula for training social workers: Towards a model. Australian Social Work, 57, 3-18.

Pomeroy, E. C. (2010). Editorial-The beginning of a new decade. Social Work, 55, 5-7. Reisch, M. (2000). Social workers and politics in the new century. Social Work, 45, 293297.

Reisch, M. (2016). Why macro practice matters. Journal of Social Work Education, $52,258-268$.

Reutebuch, T. G. (2006). Graduating BSW students' attitudes towards vulnerable populations and their preferences towards interventions to serve them. Advances in Social Work, 7, 57-66.

Ritter, J. A. (2007). Evaluating the political participation of licensed social workers in the new millennium. The Policy Practice Journal, 6, 61-78.

Rome, S., Hoechstetter, S. (2010). Evaluating the political participation of licensed social workers in the new millennium. Journal of Sociology \& Social Welfare, 37, 107-129.

Rothman, J. (2013). Education for macro intervention: A survey of problems and prospects. Pittsburgh, PA: Association of Community Organization and Social 
Administration.

Rothwell, D. W., Lach, L., Blumenthal, A., Akesson, B. (2015). Patterns and trends of Canadian social work doctoral dissertations. Journal of Teaching in Social Work, $35,46-64$.

Rountree, M. A. (2005). Integration of HIV/AIDS risk assessment educational/prevention programming and policy within domestic violence shelters $(\mathrm{PhD}$ dissertation). Arizona State University, Tempe.

Sabatier, P., Weible, C. (2007). The advocacy coalition framework: Innovations and classifications. In Sabatier, P. (Ed.), Theories of the policy process (2nd ed., pp. 189220). Boulder, CO: Westview Press.

Schneider, A., Ingram, H. (1997). Policy design for democracy. Lawrence: University of Kansas Press.

Schneider, R. L., Netting, E. (1999). Influencing social policy in a time of devolution: Upholding social work's great tradition. Social Work, 44, 349-357.

Scourfield, J., Maxwell, N. (2010). Social work doctoral students in the UK: A web-based survey and search of the Index to Theses. British Journal of Social Work, 40, 548- 
566.

Shek, D. T., Hua Lee, J., Yan Tam, S. (2007). Analyses of postgraduate social work dissertations in Taiwan: Implications for social work research and education. International Social Work, 50, 821-838.

Smith, K., Larimer, C. (2017). The public policy theory primer (3rd ed.). Boulder, CO: Westview Press.

Society for Social Work and Research. (2016). Conference program. Fairfax, VA: Author.

Stuart, P. H. (1999). Linking clients and policy: Social work's distinctive contribution. Social Work, 44, 335-347.

Svihula, J. L. (2005). Policy and politics of reform: Social Security in the United States (PhD dissertation). University of California at Berkeley, Berkeley.

Thoren, K. (2008). ‘Activation policy in action': A street-level study of social assistance in the Swedish welfare state (PhD dissertation). University of Chicago, Chicago, IL.

Vaughn, J. N. (2015). Lived experiences of military lesbians who served during the 'don't ask, don't tell' policy (PhD dissertation). Morgan State University, Baltimore, MD. 
Vohra-Gupta, S. (2010). The Convention on the Elimination of All Forms of Discrimination against Women (CDEAW): Does it achieve gender equality? Examining critical success factors through a feminist policy analysis framework $(\mathrm{PhD}$ dissertation). University of Houston, Houston, TX.

Weiss, I. (2006). Factors associated with interest in working with the poor. Families in Society: The Journal of Contemporary Social Services, 87, 385-394.

Weiss, I., Gal, J., Cnaan, R. A. (2004). Social work education as professional socialization: A study of the impact of social work education upon the professional preferences of students. Journal of Social Service Research, 31, 13-31.

Weiss, I., Gal, J., Katan, J. (2006). Social policy for social work: A teaching agenda. British Journal of Social Work, 36, 789-806.

Weiss-Gal, I. (2016). Policy practice education: Literature review. International Journal of Social Welfare, 25, 290-303.

Weiss-Gal, I. (2017). Social workers' policy engagement: A review of the literature. International Journal of Social Welfare, 26, 1468-2397.

Whitaker, T., Arrington, P. (2008). Social workers at work. NASW membership workforce study. Washington, DC: National Association of Social Workers

Whitaker, T., Weismiller, T., Clark, E. (2006). Assuring the sufficiency of a frontline workforce: A national study of licensed social workers. Executive summary. Washington, DC: National Association of Social Workers. 
Williams, A. H. (2003). Social welfare policy curriculum content in Central Europe in comparison to U.S. policy and social work education (PhD dissertation). University of South Carolina, Columbia. 